\title{
Los revocos de Medina Azahara. Parte II: Caracterización de la superficie policromada y causas de su deterioro
}

\author{
Rendering mortars in Medina Azahara. Part. II: Material \\ characterization and alteration causes
}

Fecha de recepción: 3-II-97

Fecha de acoptación: 24-III-97

Dra. M. T. BLANCO-VARELA

Instituto de Ciencias de la Construcción Eduardo Torroja (CSIC)

ESPAÑA

\section{RESUMEN}

En el presente trabajo se estudia la capa de policromia que recubre algunos de los morteros conservados a la intemperie en la ciudad de Medina Azahara. Dicha capa se caracteriza desde el punto de vista composicional y fisico, determinándose las principales causas de su deterioro.

La capa de policromia está formada por calcita y óxidos de hierro. Dicha capa es bastante homogénea y compacta. Su espesor es de 0, $\mathrm{V}$ a $1 \mathrm{~mm}$ aproximadamente.

Las capas de pintura sustentadas por morteros de cal tienen un depósito de ('aC $\mathrm{O}_{3}$, sobre los restos de policromia.

Las capas de pintura sustentadas por morteros de yeso o bastardos de cal y yeso tienen depósitos de yeso sobre los restos de policromía.

Los procesos de disolución de los revocos y la posterior cristalización de las sales en su superficie, junto con la colonización biológica, son las principales causas de deterioro de la capa de policromia de su superficie.
SUMMARY

In the present work, the depicted coat that covers some of the mortars exposed to weathering in the Medina dzahara archacological site is studied. That coat is characterized from the compositional and physical viewpoint and the main causes for its decay are determined.

The depicted coat is formed by calcite and iron oxides. It is quite compact and homogeneous. It is approximately (0.1 to I mm thick.

The depicted coats supported by lime mortars have $\mathrm{CaC}^{\mathrm{C}} \mathrm{O}_{3}$ deposits over polvchromy rests.

Depicted coats supported by gypsum mortars or mixed lime and gypsum mortars have gypsum deposits over polychromy rests.

The processes of rendering mortars dissolution and the later crystallization of salts on their surface, together with biological growth, are the main causes of the decar of the depicted coats.

\section{INTRODUCCIÓN}

Como ya se ha descrito en la primera parte de este trabajo, los muros de la ciudad de Medina Azahara, construidos con sillares de piedra arenisca, algunas albercas e incluso suelos conservan restos de los morteros de recubrimiento, en ocasiones policromados.

\section{INTRODUCTION}

As it was described in the first part of this study, the walls of Medina Azahara, built with sandstone ashlar. some reservoirs, and even the floors, still have covering mortars, sometimes with polychromy. 
El color más frecuente en las policromías de aquellos morteros que se conservan a la intemperie es el rojo, y su estado de conservación depende de la naturaleza del material que las sustenta y de las condiciones en las que se conservan.

Los objetivos de este trabajo son:

a) Determinar el espesor de la capa policromada.

b) Caracterizar los depósitos que se encuentran sobre las superficies policromadas.

c) Determinar la composición química de los pigmentos.

d) Determinar las causas de deterioro de las superficies policromadas.

\section{METODOLOGÍA DE ANÁLISIS DE LOS MATERIALES}

Se tomaron muestras de revocos policromados de color rojo en las cinco zonas o salas del Conjunto

Arqueológico descritas en la Parte I de este trabajo (1).

Todas las muestras fueron examinadas a la lupa para determinar el espesor de la capa de policromía, su estado de conservación (presencia de depósitos, crecimientos biológicos, fisuras etc.), presencia de áridos, etc.

También se estudió la superficie policromada y la sección perpendicular a la misma a través de microscopía electrónica de barrido (SEM), y se determinó su composición química por medio de microanálisis por espectroscopía de energías dispersivas de rayos X (EDX). Los datos analíticos son semicuantitativos, $y$ al examinarlos se ha de tener en cuenta que los elementos ligeros $(Z<11)$, no son detectados.

La espectroscopía de absorción IR se utilizó para confirmar la composición mineralógica de la capa pictórica y para caracterizar los depósitos encontrados sobre aquélla.

\section{RESULTADOS}

\section{Sala 1. Vivienda de Yafar}

Las superficies de los morteros MA-7 y MA-8, tomados de la zona inferior de los muros enfoscados que se encuentran en esta sala, tienen restos de policromía roja, están muy alteradas y presentan fisuras, descamamientos, depósitos, etc.
The most frequent colour in the polychromy of those mortars is red and their conservation state depends on the nature of material supporting them and on the conditions of preservation.

The aims of this work are the following:

a) To determine the width of polychromy layer

b) To characterize the deposits over the polychromic surfaces.

c) To determine the pigments chemical composition.

d) To determine decay causes of the polychromic surfaces.

\section{MATERIALS ANALYSIS METHODOLOGY}

Samples were taken from the red polychromic stuccos in the five zones or rooms of the Archaeological site described in the Part I of this work (I).

All the samples were examined through stereomicroscope to determine the polychromy layer width, its conservation state (deposits, biological growths, cracks), aggregates content, etc.

The polychromic surface and the normal section were studied through scanning electronic microscopy (SEM) and its chemical composition was determined through microanalysis by $x$-ray dispersive energies spectroscopy (XIDE). Analytical data are semiquantitative and light elements $(z \cdot 11)$ are not detected.

IR absorption spectroscopy was used to confirm the mineralogical composition of depicted coat and to characterize the deposits found over this coat.

\section{RESULTS}

\section{Room I. Yafar's House}

The surfaces of MA-7 and MA-8 mortars taken off from the walls of this room have red polychromy rests. They are very altered and show cracks, flakes, deposits, etc. 


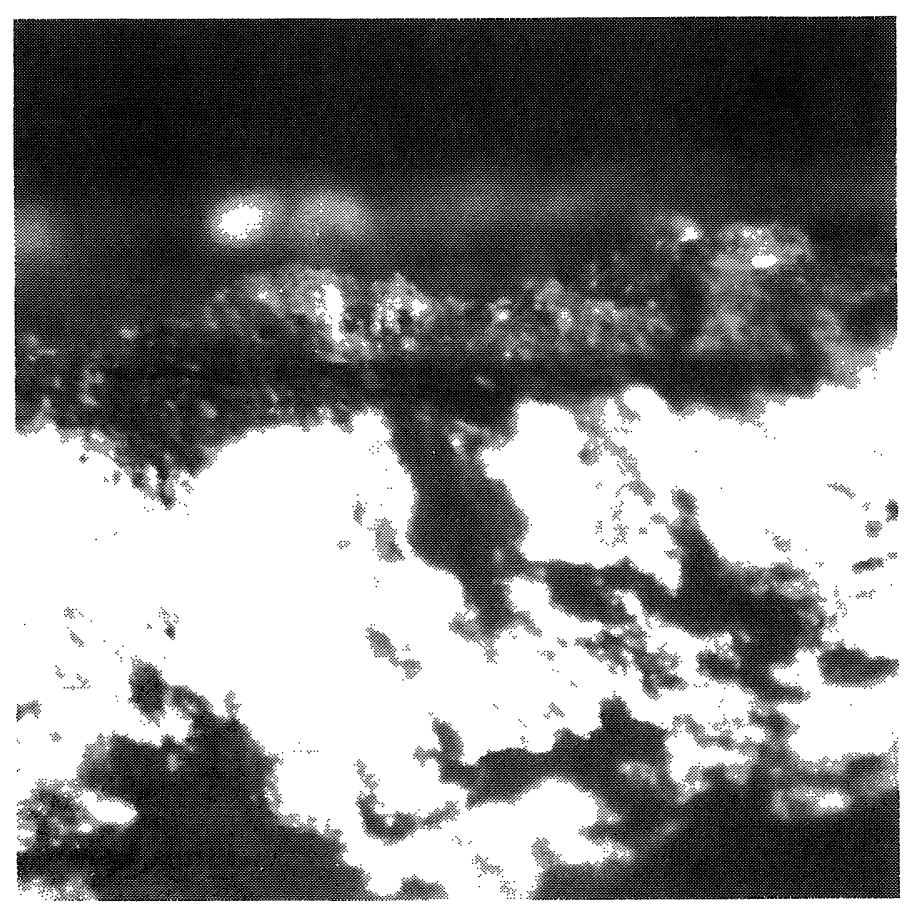

Fig. 1.- MA-7. Sección transversal donde se observa la capa pictórica sobre el mortero y los depósitos superficiales (x 21).

Fig. I.-MA-7. Transversal section where depicted coat over monarand superficial deposits are observed $(x 21)$.

La capa pictórica tiene un espesor entre 0,3 y $1 \mathrm{~mm}$ y está en algunas zonas bien adherida al substrato, mientras que en otras se ve levantada en escamas.

El análisis de estas superficies, a través de SEM y EDX, revela que los depósitos superficiales son en su mayoría, de yeso (Fig. 1). Dicho yeso procede de la disolución del mortero bastardo, base de la capa pictórica, y posterior cristalización en superficie.

En la Tabla I se muestra el rango de concentraciones elementales en los que se sitúan dichos análisis.
The depicted coat has a width between 0.3 and $1 \mathrm{~mm}$ and in some areas it sticks fast to the surface while in others it drops off in scales.

The analysis of these surfaces through SWM and .IVII show that most of the superficial deposits are of gypsum (Fig. 1). This gypsum was formed from the dissolution of mortar, base of the depicted coat. and its later crystallization on surface.

Table I shows the range in which these analyses lie.

\section{TABLA I (TABLE I)}

Rango de variación de los elementos analizados en superficie de la capa pictórica (Variation range of the elements analyzed in depicted coat surface)

\begin{tabular}{||c|c|c||}
\hline $\begin{array}{c}\text { Elemento } \\
\text { (Element) }\end{array}$ & $\begin{array}{c}\text { Capa policromada. Superficie Externa } \\
\text { (Polychromy layer. External surface) } \\
\text { \% peso (\% wt.) }\end{array}$ & $\begin{array}{c}\text { Capa policromada. Sección perpendicular } \\
\text { (Polychromy layer. Normal section) } \\
\text { \% en peso (\% wt.) }\end{array}$ \\
\hline $\mathrm{Si}$ & $9-14$ & $0-2,4$ \\
\hline $\mathrm{S}$ & $1,2-2$ & $0,7-1,6$ \\
\hline $\mathrm{K}$ & $0,3-0,5$ & $0-1,2$ \\
\hline $\mathrm{Ca}$ & $33-54$ & $40-52$ \\
\hline $\mathrm{Fe}$ & $8,3-13,2$ & $16-30$ \\
\hline $\mathrm{Al}$ & $0,8-0,9$ & $-\cdots$ \\
\hline
\end{tabular}


Estos análisis revelan que la capa pictórica está constituida por un óxido de hierro y $\mathrm{CaCO}_{3}$ casi exclusivamente, los demás elementos son, comparativamente, minoritarios.

Los análisis superficiales revelan la presencia de Si en proporciones importantes (9-14\%), muy superiores a las encontradas al analizar la sección transversal de la capa pictórica.

\section{Sala 2. Vivienda de Yafar}

En la parte inferior de uno de los paramentos de esta sala, seleccionados para su estudio, se tomó una muestra de un revoco policromado (MA-15), cuya superficie está muy deteriorada, en muchas zonas hay pérdida de capa pictórica, presenta fisuraciones, colonización biológica, depósitos de sales, (fundamentalmente de yeso) y una fina capa superficial, casi transparente, que matiza el color de la policromía (Fig. 2).

El análisis de la superficie de la capa pictórica da resultados similares a los descritos en la muestra MA-7, presentando contenidos de Si altos, que no se justifican por un solapamiento en el análisis de la señal de Si procedente del mortero base. A su vez, los análisis de la sección estratigráfica indican que la capa policromada tiene un espesor inferior a $1 \mathrm{~mm}$ y está
These analyses reveal that the depicted coat is formed mostly by iron oxide and $\mathrm{CaCO}_{3}$. The other elements are comparatively minor.

The analysis of the surface shows an important content of Si (9-14\%) much higher than that found when analyzing transversal section of the depicted coat.

\section{Room 2. Yafar's House}

In the lower part of one of the chosen walls of this room, a sample of the polychromic rendering mortar (MA-15) was taken, whose surface was severely dammaged, with loss of the depicted coat in some areas, cracks, biological growths, salt deposits (mainly of gypsum) and a thin layer, almost transparent at the surface that smooths the polychromy (Fig. 2).

The analysis of depicted surface gives similar results to those described in MA-7 sample, with high Si contents not justified by an overlapping with the Si signal from the base mortar. The analysis of stratigraphic section indicates that polychromy layer is less than $1 \mathrm{~mm}$ thick and is formed by $\mathrm{CaCO}_{3}$ and ferric oxide. Sometimes, round black particles of

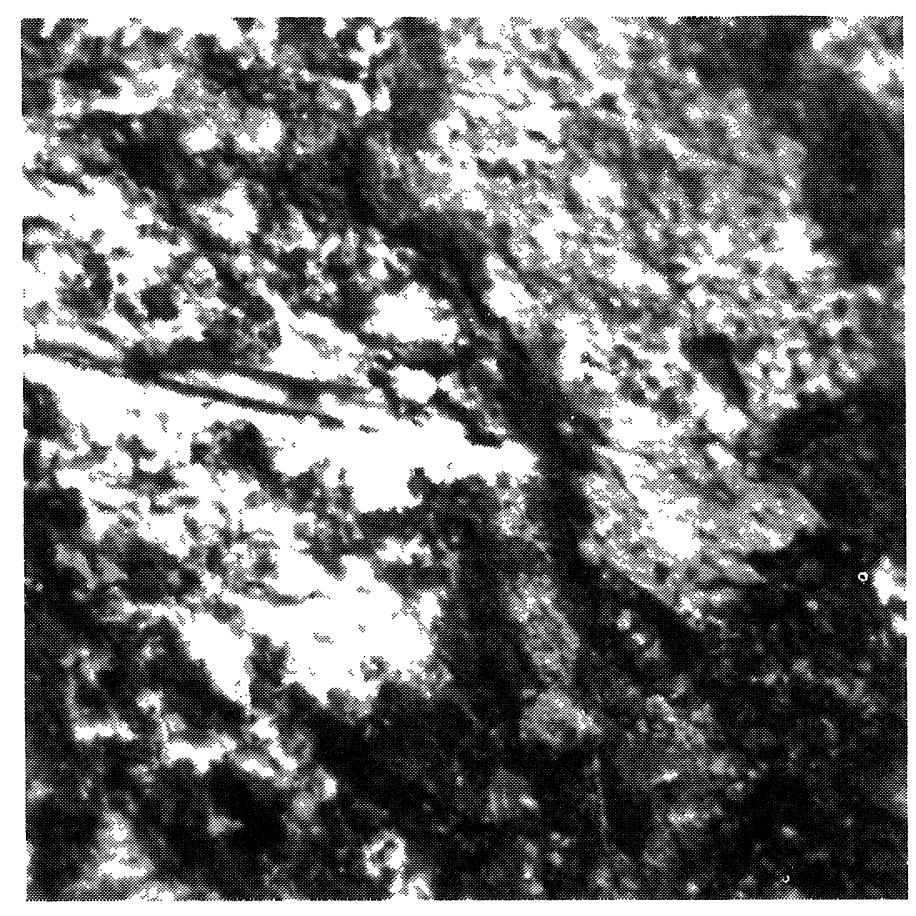

Fig. 2.- MA-15. Deterioro de la superficie policromada de mortero (x 11).

Fig. 2.- MA-15. Decay of the polychromic surface of the mortar (x 11). 
constituida por $\mathrm{CaCO}_{3}$ y óxido férrico. En ocasiones se ven partículas redondeadas de color negro, que son de óxido ferroso- férrico (magnetita). Los depósitos que se han generado por la colonización de líquenes, contienen, fundamentalmente, calcita, yeso y oxalato cálcico.

\section{Sala 3. Dar al Yund}

Sobre la capa pictórica del revoco MA-18, aparece una especie de depósito que la recubre totalmente en algunas zonas y que amortigua el color de dicha capa, haciéndola más opaca (Fig.3).

Adicionalmente, se encuentran cristalizaciones superficiales de yeso.

Los análisis puntuales, efectuados a través de SEM y EDX de la superficie policromada y de la capa superficial que la recubre, revelan una gran heterogeneidad en su composición.

En la Tabla II se dan los valores entre los que varía la composición de ambos materiales. Estos valores no son medios y han de considerarse como orientativos. Ha de considerarse también que no se analizan los elementos ligeros. ferrous-ferric oxide (magnetite), are seen. The deposits formed because of lichen growths are mainly of calcite, gypsum and calcium oxalate.

\section{Room 3. Dar al Yund}

On the depicted coat of MA-18 mortar, a deposit appears covering the coat in some zones and shades the colour, making it more opaque (Fig. 3).

Also, surface crystallization of gypsum is found.

Punctual analyses, through SEM and XDE of the polychromic surface and the surface layer covering it, show a large compositional heterogeneity.

In Table II the values between which both materials composition varies are shown. These values are not mean values and they must be considered as orientative. Also it must be considered that light elements are not analyzed.

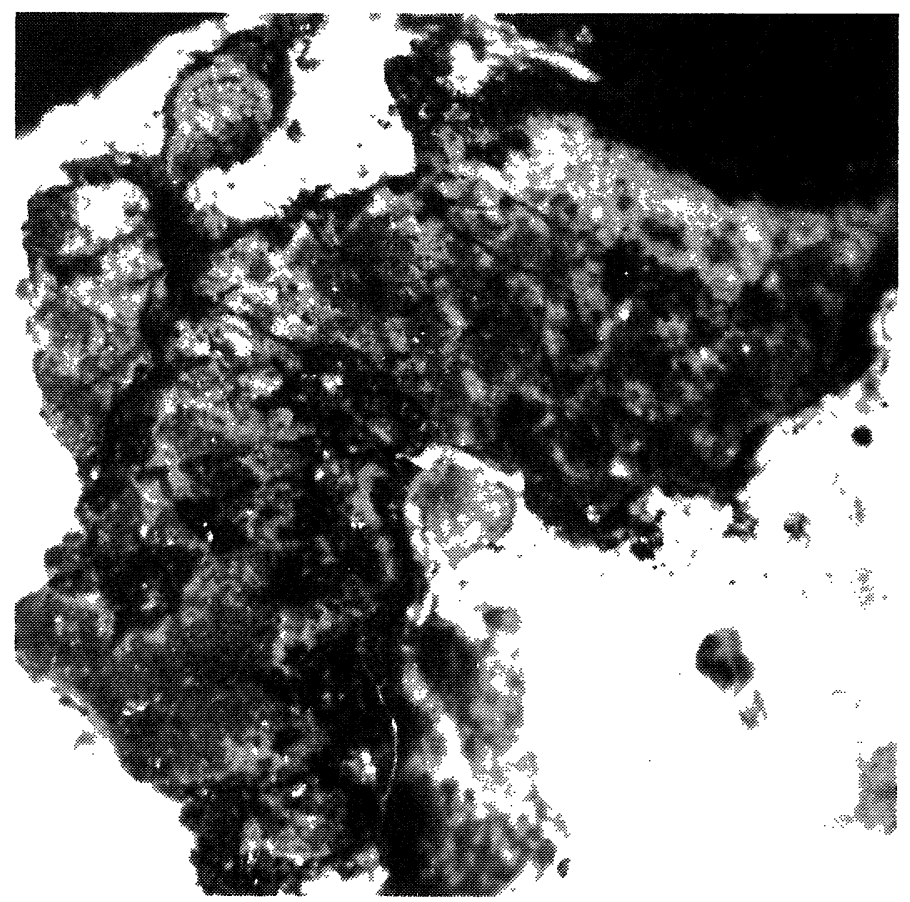

Fig. 3.- MA-18. Capa "de veladura" sobre la superficie policromada (x 19).

Fig. 3.- MA-18. "Hiding" coat over thepolychromic surface (x 19). 
Rango de valores entre los que se sitúan los análisis de la capa de pintura y capa superficial en la muestra MA-18

(Values range in which depicted coat and superficial layer analysis are placed for MA-18 samples)

\begin{tabular}{||c|c|c||}
\hline \hline $\begin{array}{c}\text { Elemento } \\
\text { (Element) }\end{array}$ & $\begin{array}{c}\text { Zona Pintura (Painting Zone) } \\
\text { \% peso (\% wt.) }\end{array}$ & $\begin{array}{c}\text { Capa superficial (Surface coat) } \\
\text { \% peso (\% wt.) }\end{array}$ \\
\hline $\mathrm{Mg}$ & $0,7-0,8$ & $2,3-3,7$ \\
\hline $\mathrm{Al}$ & $0,5-1,1$ & $1,4-2,2$ \\
\hline $\mathrm{Si}$ & $2,3-4,7$ & $16-26$ \\
\hline $\mathrm{S}$ & $0,4-1,4$ & $0-2$ \\
\hline $\mathrm{Ca}$ & $30-42$ & $13-40$ \\
\hline $\mathrm{Fe}$ & $23-32$ & $5-7$ \\
\hline
\end{tabular}

De los análisis de la zona policromada se deduce que está constituida por una sal de Calcio, $\left(\mathrm{CaCO}_{3}\right)$, y un óxido de Fe. Las cantidades de los demás elementos son muy inferiores y se pueden justificar como impurezas de las propias materias primas.

A su vez, en los análisis de la capa superficial, cabe destacar el alto contenido en Si y Ca. La presencia de $\mathrm{Ca}$, así como la de Fe podrían justificarse por la finura del depósito, ya que la porción de muestra analizada depende de la capacidad de penetración del haz de electrones y podría ser que se estuviese analizando un volumen que interesase la capa de pintura que hay bajo el depósito.

El contenido en Si es, sin embargo, extraordinariamente alto y no se puede justificar por la posible aportación de capas más profundas.

\section{Patio de los Pilares}

En la alberca del Patio de los Pilares se tomaron tres muestras de enfoscados con una capa externa policromada (MA-19, MA-20, MA21).

La superficie de la muestra MA-19 presenta restos de policromía, así como restos de un depósito superficial y colonización biológica.

La observación a la lupa de una sección perpendicular a la superficie externa (Fig. 4), muestra que la superficie policromada, cuyo espesor es similar al de las otras muestras, se encuentra fisurada longitudinalmente en algunas zonas, de modo que existe un espacio entre las dos capas resultantes, una de ellas perfectamente adherida al mortero base y la otra al depósito superficial. Esta
From the analysis of polychromic zone it is deduced that it is mainly constituted by a calcium salt , $\left(\mathrm{CaCO}_{3}\right)$ and iron oxide. The amounts of other elements are very small and they can be justified as impurities from raw materials.

In another hand, from the analysis of the superficial layer it is worth pointing out the high Si and $\mathrm{Ca}$ contents. The presence of $\mathrm{Ca}$ and $\mathrm{Fe}$ could be justified because of the deposit fineness since the portion of the sample analyzed depends on the penetration capacity of the electron beam, and possibly the analysis could be influenced by the depicted coat below it.

Si content is, however, extremely high and it cannot be justified by the possible contribution from deeper coats.

\section{The Pilares'Patio}

In the reservoir (alberca) sited in the Pilares'Patio, three stucco samples with an external polychromy layer were taken (MA-19, MA-20, MA-21).

The surface of sample MA-19 has some remainings of polychromy, rests of superficial deposits and biological growths.

The observation of a cross section of the external surface through stereomicroscope (Fig. 4), shows that the polychromic surface (whose width is similar to that of other samples) is longitudinally cracked in some zones, leaving a space between the two resulting layers. One of them is perfectly fixed to the base mortar and the other to the superficial deposit. This 


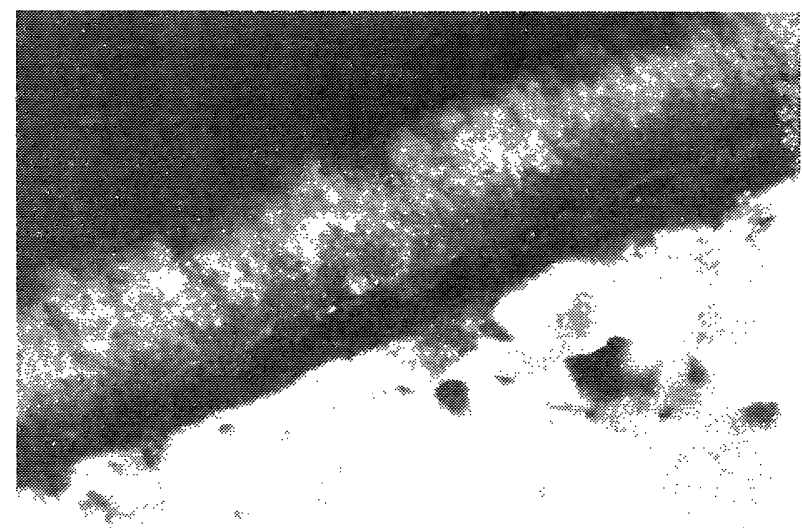

Fig. 4.- MA-19. Capa pictórica con depósitos de calcita y fisurada (x 40). Hïg. 4.-MA-19. Depicted coat with calcite deposits and crockings $(x 40)$.

fisura está , en ocasiones, rellena de cristales similares a los que constituyen el depósito.

El análisis de dicha superficie, a través de EDX-SEM, muestra que el depósito está formado exclusivamente por cristales de $\mathrm{CaCO}_{3}$. A su vez, la zona con policromía está constituida, casi exclusivamente, por $\mathrm{CaCO}_{3}$ y óxido de $\mathrm{Fe}$, es más compacta que la capa de depósito y que el mortero base.

En ninguno de los análisis se ha encontrado azufre.

Tanto la composición como la microestructura de la superficie policromada de la muestra MA-20 son muy parecidas a la de MA-19. Su espesor medio es, como en el resto de los casos, inferior a $0,5 \mathrm{~mm}$, y su adherencia al substrato, así como a la capa de carbonatos que tienen depositada en superficie, es buena. Al igual que en la muestra MA-19, en su superficie hay una fina capa de calcita y, ocasionalmente, se observan algunos depósitos de yeso, cuyo origen se interpreta como debido al ataque del $\mathrm{SO}_{2}$ atmosférico. En esta muestra no se ha observado la fisuración de la capa policromada.

Al examinar un corte transversal de la muestra MA-21, se observan dos capas pictóricas separadas entre sí por un mortero de cal compacto, de unos $5 \mathrm{~mm}$ de espesor, con áridos de tamaño inferior a $2 \mathrm{~mm}$ (Fig. 5).

Ambas capas de policromía presentan diferencias de textura y coloración. Así, la capa policromada más externa es bastante compacta, de espesor regular y su color es rojo intenso mientras que la más interna es menos compacta, su espesor es variable y presenta una coloración rosácea. El análisis de estas muestras a través de las técnicas microscópicas da resultados similares a los ya descritos anteriormente,

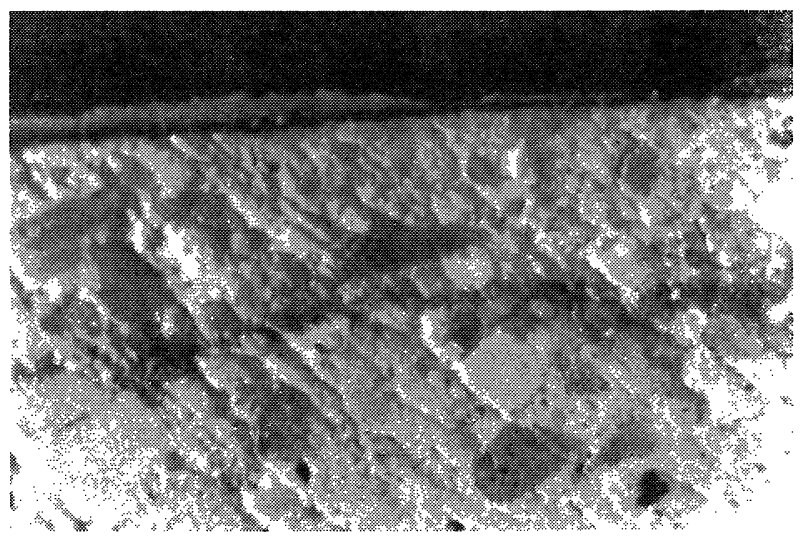

Fig. 5.- MA-21. Detalle de las dos capas de policromía (x 15).

Fig. 5.-MA-21. Detail of the two polychromy coats (x 15).

crack is sometimes filled with crystals similar to those of the deposit.

The analysis of that surface through XDE-SEM shows that the deposit is exclusively formed by $\mathrm{CaCO}_{3}$ crystals. At the same time, polychromic zone is almost exclusively constituted by $\mathrm{CaCO}_{3}$ and $\mathrm{Fe}$ oxide and it is more compact than the deposit layer and the base mortar.

Sulphur has not been found in any of the analysis.

Both the composition and the microstructure of polychromic surface of MA-20 sample are very similar to those of MA-19 sample. Its mean width is less than $0.5 \mathrm{~mm}$ (same as the others) and its adherence to the substrate and to the layer of carbonate deposited on the surface is good. Same as in $M A-19$, a thin laver of calcite exists in its surface. Occasionally, gypsum deposits are observed whose origin is due to atmospheric $\mathrm{SO}_{2}$ attack. ('racking of polychromic layer has not been observed in this case.

When examining a transverse cut of $M A-2$ I sample. two depicted coats separated by a compact lime mortar $5 \mathrm{~mm}$ thick with aggregates less than $2 \mathrm{~mm}$ in size are observed (Fig. 5).

Both polychromy layers show differences in colour and texture. The most external layer is quite compact, of regular width and it is intense red whereas the internal one is less compact with variable width and a pinkish colour. The analysis of these samples through microscopy techniques gives similar results to those formerly shown, verifying that polychromy is 
confirmándose que la policromía está constituida por $\mathrm{CaCO}_{3}$ y un óxido de $\mathrm{Fe}$ y que superficialmente sólo hay cristalizaciones de calcita.

\section{Vivienda del Servicio}

Las muestras de revoco, con su superficie externa policromada (MA-22 y MA-24), tomadas del suelo y un paramento de esta sala, son muy similares.

Su capa policromada es bastante compacta, menos porosa que el mortero que la sustenta, su espesor medio es aproximadamente de $0,3 \mathrm{~mm}$, su color rojo intenso y está constituida por calcita y óxido de hierro, similar a la ya descrita en las muestras anteriores.

En algunas zonas sobre la capa pictórica se observan depósitos de calcita, cuyo origen es similar al ya descrito en las muestras anteriores, es decir, debido a procesos de disolución del carbonato de la matriz y reprecipitación superficial.

En la superficie del mortero MA-24 se observa una intensa colonización biológica, que penetra hacia el interior del mortero y que parece ser una causa importante de su deterioro.

\section{DISCUSIÓN}

De los resultados descritos se deduce que la capa pictórica que recubre todos los revocos está constituida esencialmente por calcita y óxido férrico. El espesor de dicha capa es siempre inferior a $1 \mathrm{~mm}$.

De acuerdo con los resultados previamente obtenidos $(1,2)$ en zonas del conjunto arqueológico que originalmente eran interiores, los revocos tenían varias capas y la mas externa, base de la pintura, era de un fino mortero de yeso o bastardo de yeso y cal, en tanto que aquéllos, originalmente diseñados para estar a la intemperie, eran morteros de cal.

La base de las muestras tomadas en la Sala 1 y 2 de la Vivienda de Yafar y la de la Sala 3, Dar al Yund son morteros bastardos de cal y yeso, con áridos de arena en baja proporción.

Los análisis de EDX, hechos sobre la superficie pictórica de las muestras tomadas en la Vivienda de Yafar, dan contenidos en Si muy superiores a los medidos sobre un corte transversal de la capa de pintura. Dicha proporción de silicio no puede proceder de la capa pictórica ni del mortero bastardo que la sustenta, y dado que los análisis se han efectuado sobre las zonas más limpias de la superficie, no parece constituted by $\mathrm{CaCO}_{3}$ and an iron oxide and that, superficially, only calcite crystallization exits.

\section{Servant's Room}

The samples of rendering mortars with polychromic external surface (MA-22 and MA-24) taken from the floor and a wall of this room are very similar.

The polychromic layer is quite compact, less porous than the mortar supporting it. Its mean width is approximately $0.3 \mathrm{~mm}$, of an intense red and it is formed by calcite and iron oxide similar to those described in former samples.

In some zones over depicted coat, calcite deposits are seen. Their origin is similar to those described in former samples. This is due to dissolution of matrix carbonate and surface reprecipitation.

In MA-24 mortar surface, an intense biological growth penetrating towards inner part of the mortar is observed. It seems an important cause for its decay.

\section{DISCUSSION}

It is deduced from the results described that the depicted coat covering all the stuccos is mainly constituted by calcite and iron oxide. The width of that layer is always less than $1 \mathrm{~mm}$.

According to the results previously obtained $(1,2)$ it can be said that in the areas originally designed to be indoors, the stuccos had several layers, and the most external one, supporting the paintings, was of a thin gypsum mortar or of a mixture of gypsum and lime, while those originally designed to be in contact with the open air were of lime mortars.

The base of the samples taken in Rooms 1 and 2 of Yafar's House and in Room 3, Dar al Yund, are lime/ gypsum mixed mortars with low proportion of sand aggregates.

$X D E$ analysis carried out on depicted coat of samples taken from Yafar's House gives Si contents much higher than those measured on cut of the depicted coat. That silicon content cannot come from the depicted coat nor from the mixed mortar supporting it. As the analysis have been carried 
proceder tampoco de un posible mortero sobrepuesto que haya existido en el pasado.

Al examinar a la lupa la muestra MA-18 tomada de la Sala 3 Dar al Yund, se observa la presencia de una fina capa o veledura, insoluble en ácido, que cubre en parte la pintura y matiza o suaviza su color. El contenido en $\mathrm{Si}$ de ésta es muy superior al obtenido en zonas de pintura exentas de dicha capa y no se puede justificar por la posible aportación de capas más profundas.

Aun cuando no hay certeza, los análisis apuntan a que las superficies policromadas de estos morteros podrían haber sido tratadas con un producto a base de silicio para su consolidación. Sin embargo, dada la distancia en el tiempo en que se han efectuado las reparaciones en estas zonas del conjunto arqueológico (década de 1980 en la Vivienda de Yafar y de 1950 en la de Dar al Yund) y los distintos arqueólogos que las dirigieron, no parece muy probable que se hubiese repetido la misma solución.

La deposición de yeso en la superficie, transportado en disolución desde el interior del material y cristalizando en la misma, se revela como una causa de su deterioro junto con la colonización biológica. Naturalmente, la fácil solubilización del yeso en la base de la pintura por el agua de lluvia conduce a una pérdida de adherencia y a una descamación y despegue de la pintura.

En las muestras tomadas en el Patio de los Pilares y en la Vivienda del Servicio, la capa de pintura se sustenta en morteros de cal y está bien adherida a su base.

Las muestras tomadas de la alberca presentan sobre la superficie una capa de calcita que procede de la solubilización de la calcita del mortero base y posterior precipitación en la superficie de evaporación.

En estos procesos de disolución-precipitación, el frente de evaporación se desplaza perpendicularmente a la superficie externa en función de la relación existente entre la velocidad de evaporación y la de acceso de agua. Esto da lugar a precipitaciones de sales en la superficie externa (eflorescencias) a alguna distancia de la superficie (subeflorescencias) o en el interior del material.

La precipitación de subeflorescencias de calcita ha determinado entonces la fisuración de la capa pictórica en la muestra MA-19, y el relleno, en algunos casos, de dicha fisura por cristales de calcita.

En la muestra MA-19, los procesos de disoluciónprecipitación ya descritos han dejado en su superficie una fina capa de calcita, pero no han conducido la fisuración de la capa policromada. out on the most tidy zones of the surface, it does not seem to come from a mortar existing in the past.

When examining under stereo microscope $M A-18$ sample, taken from Room 3 I ar al Yund. the presence of a thin layer, acid insoluble, partly covering the painting and smoothing the colour is observed. The Si content in this layer is much higher than the one obtained from painted zones that does not have this layer, and it cannot be justified by a possible supply from the deeper layers.

The analysis shows that the polychromic surfaces of these mortars could have been treated with a silicon based product for their consolidation. However, taking into account the gap of time between Yafar's House repair (1950) and Dar al Yund repair (1980), with the intervention of different archeologists it seems' very improbable that the problem was solved the same way.

(iypsum deposited on surface, disolved and conveyed from the inner part of the material to the surface and crystallized on the surface, is the main cause of decay together with the biological growths. The easy dissolution of gypsum due to rain water absorbed by the coat that supports the painting leads to adherence loss, flaking and loosen paint.

In the samples taken from the Pilare's Patio and Servant's Room, depicted coat is supported by lime mortars and is well fixed to their base.

Samples taken from alberca present a calcite laver on their surface coming from the calcite dissolution in the base mortar and later precipitation in the evaporation surface.

In these dissolution-precipitation processes; evaporation front moves perpendicularly to the external surface as a function of the relation between evaporation rate and water access rate. This gives place to salts precipitations in the external surfaces (efflorescences), at some distance of the surface (subefflorescences) or in the material inner part.

Calcite subefflorescences precipitation has determined the cracking of the depicted coat in MA-19 sample, and, in some cases, the filling of the cracks with calcite crystals:

In MA-19 sample, dissolution-precipitation processes described, have leaved in its surface a calcite thin layer. but there is no craking in the depicted coat. 
En la muestra MA-21, la existencia de las dos capas policromadas parece indicar que la muestra procede de una zona que se alteró en su momento y fue reparada con un revoco de cal y una nueva capa de policromía.

En este tipo de muestras las principales causas de deterioro de la superficie pictórica son: la cristalización superficial o en forma de subeflorescencias de calcita y la colonizació biológica.

\section{CONCLUSIONES}

$\left.1^{a}\right)$ Todos los soportes de policromía de las zonas originalmente interiores, son morteros bastardos. Todos los soportes de policromía en las zonas exteriores o en contacto con agua son morteros de cal

$\left.2^{a}\right)$ En todos los casos la capa de policromía está formada por calcita y óxidos de hierro. Dicha capa es bastante homogénea y compacta. Su espesor es de 0,1 a $1 \mathrm{~mm}$ aproximadamente.

$3^{a}$ ) Las capas de pintura sustentadas por morteros de cal tienen un depósito de $\mathrm{CaCO}_{3}$ sobre los restos de policromía. Estos depósitos proceden de la solubilización de la calcita del mortero por aguas carbonatadas y posterior evaporación y deposición de la sal en la superficie.

$\left.4^{a}\right)$ Las capas de pintura sustentadas por morteros de yeso o bastardos de cal y yeso tienen depósitos de yeso sobre los restos de policromía. Estos depósitos proceden de la solubilización del yeso del mortero por aguas de lluvia y posterior evaporación y deposición de la sal en la superficie.

$5^{a}$ ) Los procesos de disolución de los revocos y la posterior cristalización de las sales en su superficie, junto con la colonización biológica, son las principales causas de deterioro de la capa de policromía de su superficie.

\section{AGRADECIMIENTOS}

La autora agradecen a la Consejería de Cultura de la Junta de Andalucía la subvención concedida a este trabajo, a la Dirección del Conjunto Arqueológico las facilidades dadas para su ejecución $y$, en especial, a $D^{a}$ Elisa Pinilla, por su apoyo y colaboración.
In $M A-21$ sample, the existence of two depicted coats indicate that the sample was located in a zone that once was altered and then repaired with a lime stucco and a new polychromy layer.

In these type of samples, the main decay causes of the depicted coats are: superficial crystallization or calcite subefflorescences and the biological growth.

\section{CONCLUSIONS}

$\left.1^{a}\right)$ All the polychromy supports of the originally inner zones are mixed mortars. All the polychromy supports in external zones or zones in contact with water are lime mortars.

$\left.2^{a}\right)$ In all cases polychromy layer is formed by calcite and iron oxides. That layer is quite homogeneous and compact. Its width is of 0.1 to $1 \mathrm{~mm}$ approximately.

$\left.3^{a}\right)$ Depicted coats supported by lime mortars have $\mathrm{CaC}_{3}$ deposits on polychromy rests. These deposits come from the dissolution of caicite mortar by carbonated waters and later evaporation and deposition of the salt on the surface.

$\left.4^{a}\right)$ Depicted coats supported by gypsum or mixed gypsum and lime mortars have gypsum deposits on the polychromy rests. These deposits come from the dissolution of gypsum mortar due to rain water and later evaporation and deposition of salts on the surface.

$\left.5^{a}\right)$ Rendering mortars dissolution processes and the later crystallization of salts in their surface, together with biological growth are the main causes of decay of the depicted coat.

\section{ACKNOWLEDGEMENTS}

Author thanks the Consejeria de Cultura de la Junta de Andalucia for the financial aid granted, the Board of Directors of the Conjunto Arqueologico for the facilities entrusted, and specially to Ms. Elisa Pinilla for her support and collaboration in the achievement of this work.

\section{BIBLIOGRAFÍA}

(1) BLANCO-VARELA M.T.; PUERTAS F. y PALOMO A.: "Los revocos de Medina Azahara. Parte I Caracterización del material y procesos de alteración". Materiales de Construcción vol.47, ${ }^{\circ} 245$, pp 29-43, 1997. 
(2) SAIZ JIMÉNEZ C.; HOYOS, M. y BLANCO-VARELA, M.T.: "Estudio de los procesos de alteración de los materiales pétreos y estucos de Madinat al Zahra". Estudio diagnosis de los Conjuntos y yacimientos arqueológicos de la Comunidad Autónoma Andaluza en su contexto geomorfológico, biológico y clímatico (1995).

(3) LEWIN SEIMUR, Z.: "The mechanism of masonry decay through crystallization" Coonservation of Historic Stone Buildings and monuments. Report of the Committee on Conservation of Historic Stone Buildings and Monuments, National Academic Press, Washington, D.C., pp. 120-144 (1982).

\section{publicaciones del IETCC/CSIC}

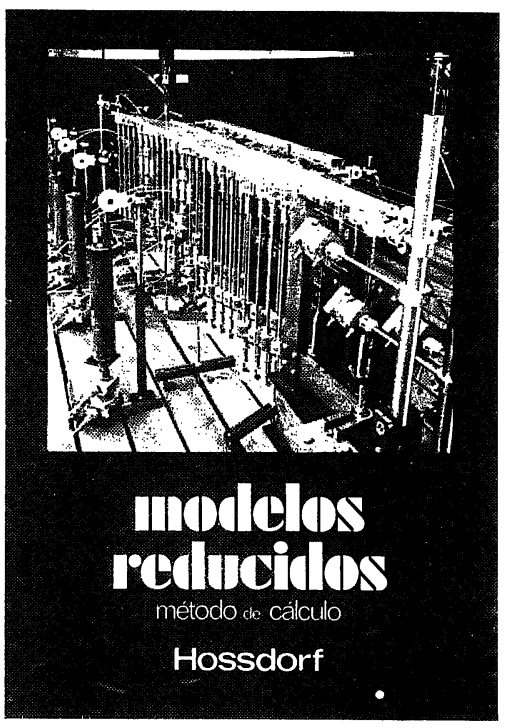

Modelos reducidos. Método de cálculo

\footnotetext{
H. Hossdorf, Ingeniero Civil
}

La técnica de los ensayos en modelos reducidos de estructuras sufre hoy dia una decisiva metamorfosis. Hasta hace poco era un medio más bien de artesania, que no siempre era tomado en serio por los academicos teorizantes para comprender el comportamiento resistente de las estructuras complejas $y$ al que se acudió las más de las veces, como a un ültimo remedio debido a sus indiscutibles insuficiencias. Sin embargo, en poco tiempo y gracias a su conexión con los ordenadores digitales, se ha transformado en un instrumento cientificamente valioso, que no puede quedar a un lado en la práctica diaria del Ingeniero Proyectista.

Un volumen encuadernado en cartoné plastificado con lomo de tela, de $17 \times 24 \mathrm{~cm}$, compuesto de 250 páginas, 158 figuras y fotografias.

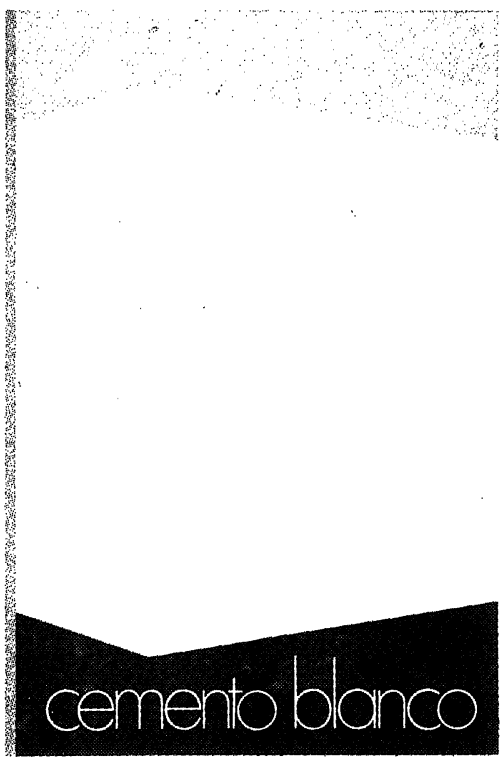

\section{Cemento blanco}

Julián Rezola

Ingeniero Quimico Dipl. I. O. S.

Sabido es que existe una extensa y documentada bibliografia sobre ef cemento gris: en cambio, no puede decirse lo mismo acerca del cemento portland blanco, ya que los escritos existentes se refieren tan sólo a algunas peculiaridades que le distinguen de aquél.

El autor nos ofrece sus profundos conocimientos y su larga experiencia tanto en laboratorio como en fabricación.

Là parte descriptiva del libro se complementa con gráficos, diagramas y fotografias de gran utilidad gráficos, diagramas y fotografias de gran utilidad,
destinados a conseguir la aplicación apropiada de este aglomerante. Un volumen encuadernado en cartoné policerado, de
$17,4 \times 24,3 \mathrm{~cm}$, compuesto de 395 páginas numerosas figuras, tablas y ábacos.

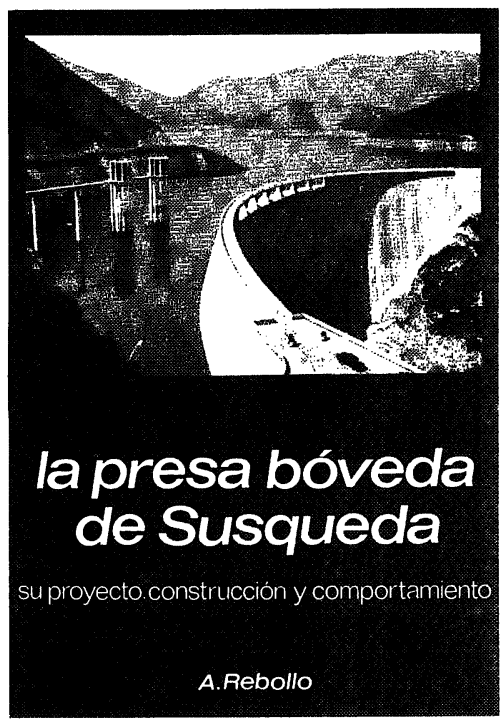

La presa bóveda de Susqueda

A. Rebollo,

Dr. Ingeniero de Caminos

El esfuerzo del constructor de presas se sitúa, por su pretensión de perennidad, a contracorriente de las tendencias de la civilización actual, caracterizada por lo fungible. Pueden evocarse las 10.000 grander.pros que gerontológicos para mantener $y$ perfeccionar su sencio y garan parar manion de perens, grandes a mequeñas, son podas nuevas riesgos ecologicos $y$ a veces, catastróficos, que aumentan con el envejeciniento, la grontologia de las presas es todo un emplazo. La accion alogia de de Arturo Rebollo en este terreno marca un camino a seguir para todos los que aman su propia obra con la devoción paternal que ét ha puesto en Susqueda.

Un volumen encuadernado en cartoné plastificado con lomo de tela de $18 \times 24.5 \mathrm{~cm}$ compuesto de 408 páginas, 330 figuras y fotografias y 39 tablas. 